\title{
BIOEDUSCIENCE
}

ISSN: 2614-1558

\section{Effect of Exposure to E-Cigarette Smoke on Lung Histology of Balb/c Male Mice (Mus musculus L.)}

\author{
Eva Tyas Utami ${ }^{*}$, Bella Dwi Arifianti ${ }^{1}$, Mahriani $^{1}$, Susantin Fajariyah ${ }^{1}$ \\ ${ }_{1}^{1}$ Department of Biology, Faculty of Mathematics and Natural Sciences, Jember University, Jln. Kalimantan 37 Jember, Indonesia 68121 \\ *Correspondent email: evatyas.utami@gmail.com
}

\section{ARTICLE INFO}

Article history:

Received: 24 July 2020

Accepted: 10 Des 2020

Published: 31 Des 2020

\section{Keyword:}

Alveoli septa thickness

Bronchioles mucosa

Electronic cigarette

Histopathology

\section{A B S T R A C T}

Background: Electric cigarette is a type of cigarette that change the liquid containing nicotine and other ingredients in the form of steam. This research aimed to identify the effect of exposure to ecigarette smoke towards the thickness of bronchioles mucosa and the alveolar septa on male Balb'C mice (M. musculus). Methods: This research was an experimental design used 24 male divided into four groups, i.e., control dan three treatment groups. Treatment groups were given different volume of e-cigarettes liquid, i.e., $1 \mathrm{ml} ; 2 \mathrm{ml}$; and $4 \mathrm{ml}$. The exposure of e-cigarette was done in 4 weeks, respectively. Results: Electric cigarette exposure with different fluid volumes leads to an increase in the bronchioles mucosa's thickness and the alveoli septa. Increasing the volume of fluid used results in an increase in bronchioles mucosal thickness, but decreases the alveoli septa's thickness, resulting in destruction and dilatation of the alveoli. Conclusion: Exposure to e-cigarette smoke with a liquid volume of $1 \mathrm{ml}$ affects the increase in the average thickness of the bronchial mucosa and alveoli septa. An increase in the average thickness of the bronchioles mucosa occurs along with increased fluid volume in exposure to e-cigarette smoke.

Pengaruh Paparan Asap Rokok Elektrik terhadap Histologi Paru Mencit (Mus musculus L.) Strain Balb/c Jantan

\section{A B S T R A K}

Background: Penggunaan rokok elektrik di Indonesia pada tahun 2018 mencapai 2,1 juta orang dan diprediksi akan terus meningkat pada tahun 2019. Selama ini penggunaan rokok elektrik dianggap tidak berpengaruh terhadap sistem pernafasan. Tujuan dari penelitian ini adalah untuk mengetahui pengaruh paparan asap rokok elektrik terhadap tebal mukosa bronkiolus dan tebal septa alveolus mencit (M. musculus) Strain Balb/c jantan. Metode: Penelitian eksperimental ini menggunakan 24 mencit (M. musculus) Strain Balb/c jantan yang dibagi menjadi 4 kelompok yaitu: kontrol dan 3 perlakuan paparan asap rokok elektrik dengan volume cairan $1 \mathrm{~mL} ; 2 \mathrm{~mL}$; dan $4 \mathrm{~mL}$. Paparan asap rokok dilakukan selama 4 minggu. Hasil: Paparan asap rokok dengan volume cairan $1 \mathrm{~mL}$ meningkatkan tebal mukosa bronkiolus dan septa alveolus. Volume cairan yang semakin meningkat mengakibatkan peningkatan ketebalan mukosa bronkiolus, namun menurunkan tebal septa alveolus. Paparan asap rokok pada volume cairan $4 \mathrm{~mL}$ mengakibatkan destruksi septa dan pelebaran alveolus. Kesimpulan: Paparan asap rokok elektrik dengan volume cairan 1, 2, dan $4 \mathrm{~mL}$ berpengaruh terhadap rata-rata tebal mukosa bronkiolus dan tebal septa alveolus. Perlu dilakukan penelitian lebih lanjut terhadap histopatologi bronkiolus dan paru.

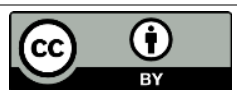

(C) 2020 by authors. License Bioeduscience, UHAMKA, Jakarta. This article is open access distributed under the terms and conditions of a Creative Commons Attribution (CC-BY) license.

\section{Introduction}

An electric cigarette is one type of cigarette that is currently favoured by people in the world, including in Indonesia. Unlike conventional cigarettes, e-cigarettes are cigarettes that use battery power to convert liquids containing nicotine and other substances into vapour so they can be inhaled as in conventional cigarettes (Kuschner et al., 2011). The use of e-cigarettes is considered safe because the nicotine level in e-cigarette liquid can be regulated by the user to be used as an alternative to reducing addiction to conventional cigarettes (Garcia-Arcos et al., 2016). However, it is known that in addition to nicotine, e-cigarettes also contain ingredients that are 
harmful to taste, and humectants (Propylene glycol and Vegetable glycerin) (Stratton et al., 2018)

Exposure to compounds in e-cigarettes, including nicotine, can negatively impact health, including disorders of the nervous system, digestive system, eyes, cancer, and the respiratory system such as irritation of the pharynx and dry cough (Meo \& Al Asiri, 2014). Smoking habits can cause emphysema in the lungs, characterized by enlargement of the distal bronchioles' air spaces and damage to the interalveolar walls. The irritation caused by smoking will stimulate the destruction or interfere with elastin synthesis in the interalveolar septa (Mescher, 2016).

The results of research by Garcia-Arcos et al. (2016) stated that exposure to e-cigarettes containing $18 \mathrm{mg} / \mathrm{mL}$ nicotine for one hour in A/J strain mice for two weeks and four months could cause increased cell inflammation in Bronchoalveolar lavage fluid (BALF), increased airway hyperreactivity, apoptosis, lung cells, mucus production, and inflammation. Mice A/J are commonly mice used in testing for carcinogenic compounds. These strains can be produced in the laboratory by breeding up to several generations, for example, 30 generations. When used for tumour research, this strain's weakness is the low frequency of mammary gland tumours (Nugroho, 2018). The results of research by Sartika et al. (2018) showed that exposure to e-cigarette smoke for 30 minutes with a dose of $6 \mathrm{mg}$ of nicotine in 2-2.5 months male for three weeks could cause the septa alveoli to experience thickening as a form of defence mechanism against e-cigarette smoke. The use of e-cigarettes can trigger oxidative stress and inflammation in rat lungs (Lerner et al., 2015). As the main organ affected by e-cigarette exposure, the lungs will experience fatal damage and increased exposure to different volumes of e-cigarette fluids. So far, research on the impact of e-cigarette exposure has been mostly carried out on the lung trachea structure.

The purpose of this study was to determine the effect of e-cigarette exposure, in this case, the effect of increasing the volume of e-cigarette fluid on the lung histology of Balb/c male mice (M. musculus) on the bronchioles and alveoli.

\section{Methods}

\section{Scope of Research}

Research and observations of pulmonary histology preparations were conducted at the Zoology Laboratory of the Biology Department, Faculty of Mathematics and Natural Sciences, Jember University. The histological preparations were made at RSD dr. Soebandi Jember. The tools used in this study include cages, drinking bottles of mice, feeding containers for mice, surgical boards, surgical instruments, digital scales, rotary microtome biobased, organ bottles, vertical staining jar, OptiLab Advance, hot plate, Olympus CX-21, microscope, vaping. Box, e-cigarette Doi: $10.22236 /$ j.bes/425319 generator (vapour), aerator, air pump vacuum and blow, object glass and cover glass.

The materials used in this study consisted of tested animals in the form of $24 \mathrm{Balb} / \mathrm{c}$ male mice (Mus musculus L.) aged 6 to 8 weeks (Stevani, 2016) with body weights ranging from 30-35 grams obtained from the Center for Veterinary Farma (Pusvetma). Surabaya, broiler pellet feed (BR1 Plus), distilled water, the liquid used for electric cigarettes with strawberry oatmeal flavour containing a dose of $6 \mathrm{mg}$ of nicotine per $\mathrm{mL}$, solution Phosphate Buffer Saline (PBS), $10 \%$ formalin, $0.9 \% \mathrm{NaCl}$, alcohol, (30\%; 50\%; 70\%; 95\%; absolute), paraffin, glycerin, albumin, xylol, entelan, and Haematoxylin Eosin (HE) as a dye, and chloroform

\section{Experimental Design}

This is an experimental research using a completely randomized design method (CRD). This study used 24 male mice (M. musculus) strain Balb/c aged 6 to 8 weeks, with 30-35 grams of body weight. Mice were divided into four groups, each using six mice as repetitions, and Group 1 was control without exposure to cigarette smoke. The other three groups are treatment groups. Mice were exposed to ecigarette smoke with different volumes of e-cigarettes liquid, respectively $1 \mathrm{~mL}, 2 \mathrm{~mL}$, and $4 \mathrm{~mL}$. Giving exposure to e-cigarette smoke is carried out every day for four weeks (El Golli et al., 2016).

\section{Procedure}

Mice in the control group (group 1) were kept without exposure to e-cigarette smoke. Group 2 was the group of mice that were exposed to e-cigarettes with a liquid volume of $1 \mathrm{~mL}$. Exposure is carried out once for one minute, then rested for 15 minutes until the e-cigarette smoke disappears. In group 3, e-cigarette exposure used a liquid volume of $2 \mathrm{~mL}$; e-cigarette exposure was carried out twice in the same way. Likewise, in group 4, exposure to ecigarettes with a liquid volume of $4 \mathrm{~mL}$ was carried out four times with the same method.

Cigarette smoke exposure was carried out by inhalation for four consecutive weeks in a vaping box with a variation of the fluid volume of $1 \mathrm{~mL} ; 2 \mathrm{~mL}$; and $4 \mathrm{~mL}$. The vaping box is made of glass with $40 \times 30 \times 25 \mathrm{~cm}^{3}$ and has an aerator hole and an air hole. The air pump vacuum and blow aerator functions as an air pump to remove air and a suction vacuum to suck smoke from heating liquids in e-cigarettes.

After the exposure to cigarette smoke ended, the mice were anaesthetized with chloroform $0.5 \mathrm{~mL}$ followed by necropsy, then placed on a surgical board in a supine position for surgery. Surgery was performed on the mice's abdomen and thorax to extract the left lobe lung organs and washed it with $0.9 \% \mathrm{NaCl}$. The left lobe lung organ was divided into three parts, then a third of the middle part was taken, and the lungs were put into an organ bottle 
containing a fixative in the form of a $10 \%$ formalin solution with PBS solvent. The lung organs are then continued in the process of making pulmonary histological preparations. The method used in this study was the paraffin method which was carried out by fixation, dehydration, clearing, infiltration, embedding, section, staining affixing and mounting (Suntoro, 1983). The staining process uses Eosin Hematoxylin dye.

\section{Data Collection and Data Analysis}

Lung histological measurements in this study included the thickness of the bronchial mucosa and the thickness of the alveolar septa. In each group, six preparations were observed with three bronchioles in each preparation. This was done because only three bronchioles were found in each preparation, which appeared intact using an Olympus CX-21 and OptiLab Advance microscope. For each bronchiolus, measurements were taken three times, namely the part that looked thickest, medium, and thin, then averaged. Bronchiolar mucosal thickness measurements were measured starting from the bronchial mucosa to the surface lumen of the bronchioles. A total of 18 bronchioles were observed. bronchioles in the treatment group were in the $1 \mathrm{~mL}$ group, namely $27.98 \pm 1.67 \mu \mathrm{m}$; in the $2 \mathrm{~mL}$ group, namely $29.00 \pm$ $0.73 \mu \mathrm{m}$; and in the $4 \mathrm{~mL}$ group, namely $33.27 \pm 1.64 \mu \mathrm{m}$. Meanwhile, exposure to e-cigarette smoke with a volume of $1 \mathrm{~mL}, 2 \mathrm{~mL}$, and $4 \mathrm{~mL}$ for four weeks increased the bronchial mucosa thickness. The thickness of the bronchial mucosa of mice (M. musculus) the male Balb/c strain can be seen in Figure 1.

We can also see the measurement of the average thickness of the alveolar septa after exposure to e-cigarette smoke in Table 1. Based on the table, it can be seen that the mean thickness of alveolar septa in the control group is $15.01 \pm 3.23 \mu \mathrm{m}$, the mean thickness of the alveolar septa in the treatment group in the $1 \mathrm{~mL}$ group is $21.80 \pm 1.90 \mu \mathrm{m}$; in the $2 \mathrm{~mL}$ group is $18.34 \pm 2.34 \mu \mathrm{m}$; and in the $4 \mathrm{~mL}$ group, namely $16.43 \pm 2.04 \mu \mathrm{m}$.

The histological structure of the male alveolar mice (M. musculus) Balb/c strain can be seen in Figure 2. On exposure to e-cigarettes with a fluid volume of $4 \mathrm{~mL}$,

\section{Discussions}

Based on the Duncan Multiple Range Test results, the average thickness of the bronchial mucosa in the control

Table 1. The average thickness of bronchial mucosa and alveolar septa after exposure to-cigarette

\begin{tabular}{ccc}
\hline Treatment & Average bronchial thickness $\underline{\underline{x} \pm \mathrm{SD}) \mu \mathrm{m}}$ & The average thickness of alveolar septa $(\underline{x} \pm \mathrm{SD}) \mu \mathrm{m}$ \\
\hline Control & $21.27^{\mathrm{a}} \pm 1.57$ & $15.01^{\mathrm{a}} \pm 3.23$ \\
1 & $27.98^{\mathrm{b}} \pm 1.67$ & $21.80^{\mathrm{c}} \pm 1.90$ \\
2 & $29.00^{\mathrm{b}} \pm 0.73$ & $18,34^{\mathrm{b}} \pm 2.34$ \\
4 & $33.27^{\mathrm{c}} \pm 1.64$ & $16.43^{\mathrm{ab}} \pm 2.04$ \\
\hline
\end{tabular}

Alveolar septa thickness measurements were carried out on the alveolar septa section using the same tool as the previous analysis. Each alveolus was measured three times the part that looked thickest, middle, and thin, then averaged. Alveolar observations were carried out for 100 alveoli in each lung preparation so that in each treatment group, 600 alveoli were observed.

The data obtained in the form of bronchiolar mucosal thickness and alveolar septa thickness will then be analyzed using the test one way Anova with a confidence level of $95 \%$ or $\alpha=0.05$ to see the effect of the volume of fluid used in exposure to e-cigarette smoke on the bronchiolar mucosal thickness and alveolar septa thickness. Furthermore, to determine the significant difference between the test groups, the Duncan Multiple Range Test (DMRT) (Steel \& Torie, 1993).

\section{Results}

Measurements of the bronchial mucosa's average thickness after exposure to e-cigarette smoke can be seen in Table 1. Based on Table 1, it can be seen that the average thickness of the bronchial mucosa in the control group is $21.27 \pm 1.57 \mu \mathrm{m}$, the average mucosal thickness group showed significant differences with the e-cigarette exposure treatment group with a fluid volume of $1 \mathrm{~mL}, 2$ $\mathrm{mL}$, and $4 \mathrm{~mL}$. The mean bronchial mucosal thickness in the e-cigarette exposure treatment group with a fluid volume of $1 \mathrm{~mL}$ and $2 \mathrm{~mL}$ was not significantly different. The mean thickness of the bronchial mucosa in the e-cigarette exposure treatment group with a fluid volume of $4 \mathrm{~mL}$ was significantly different from the control group, the ecigarette exposure treatment group with a fluid volume of 1 $\mathrm{mL}$, and $2 \mathrm{~mL}$, and showed an average thickness of the thickest bronchial mucosa. Along with the increase in the volume of fluids used in e-cigarette smoke exposure, it is also suspected that there is an increase in nicotine levels in inhaled e-cigarette smoke. The increase in the bronchial mucosa's mean thickness is thought to be influenced by the increase in the volume of fluid used in e-cigarette exposure.

The results showed that an increase in the volume of fluid used in exposure to e-cigarette smoke caused an increase in the bronchial mucosa's mean thickness. This is thought to be because the nicotine contained in e-cigarettes that are evaporated will produce carbon monoxide (CO) compounds free radical compounds (Casebolt et al., 2019). 

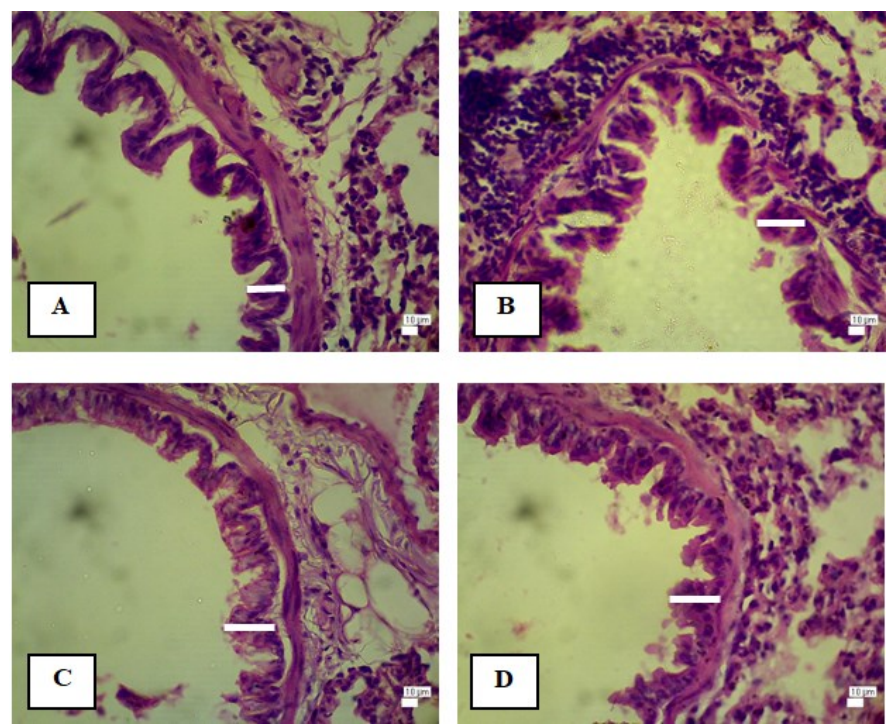

Figure 1. The thickness of the bronchial mucosa of mice (indicated by white arrows) after exposure to e-cigarette smoke. Microscope magnification $400 \mathrm{x}$. (A) Control, (B) $1 \mathrm{~mL}$, (C) $2 \mathrm{~mL}$, (D) $4 \mathrm{~mL}$ Fluid Volume
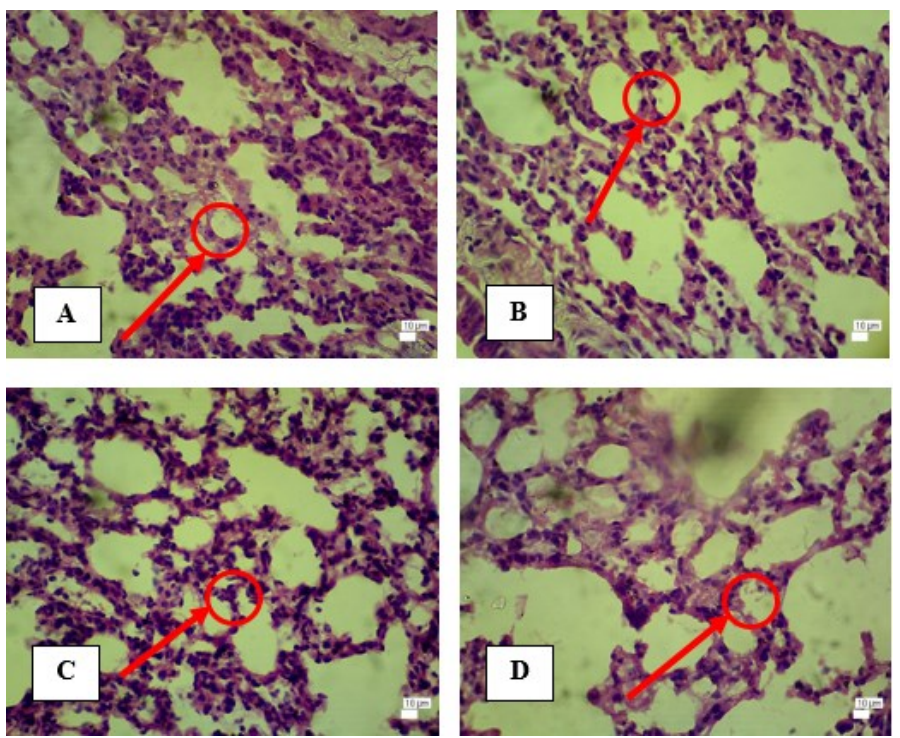

Figure 2. The thickness of the alveolar septa of mice (indicated by white arrows) after exposure to e-cigarette smoke. Microscope magnification 400 x. (A) Control, (B) 1 mL, (C) 2 mL, (D) 4 mL Fluid Volume.

The nicotine in cigarettes can cause oxidative stress (Lerner et al., 2015). The more free radical compounds that enter the body will cause an imbalance between free radical compounds and antioxidants in the body to trigger oxidative stress (Suryadinata, 2018). Oxidative stress will trigger the release of 8-isoprostane, which will activate interleukin 8 (IL-8) and trigger the inflammatory process. Oxidative stress will also activate the nuclear factor kappalight-chain-enhancer of activated B cells (NF-KB) (Macnee \& Rahman, 2001).

$N F-\kappa B$ controls several vital genes in immune and inflammatory processes such as Granulocyte-macrophage colony-stimulating factor (GMCSF), interleukin 6 (IL-6), interleukin 2 (IL2) and tumour necrosis factor-alpha (TNF$\alpha$ ). TNF- $\alpha$ is a cytokine that will trigger neutrophils and endothelial activation by increasing the release of adhesion molecules that trigger neutrophil and macrophage infiltration in target cells (Vinay et al., 2003). Neutrophils will migrate from the blood capillaries to the tissues to form Transforming Growth Factor- $\alpha$ (TGF- $\alpha$ ), which will trigger the Epidermal Growth Factor Receptor (EGFR). EGFR will prevent the apoptotic process of ciliated cells and signal IL-13 from triggering ciliated cells' differentiation into Goblet cells (Tyner et al., 2006). The presence of neutrophil infiltration and goblet cell hyperplasia will cause thickening of the bronchial mucosa. According to Shu et al. (2017), exposure to cigarette smoke containing nicotine 1 $\mathrm{mg} / \mathrm{mL}$ in mice for ten weeks can cause thickening of the bronchial walls, infiltration of macrophages and neutrophils, and Goblet cell hyperplasia. Exposure to ecigarette smoke containing $6 \mathrm{mg} / \mathrm{mL}$ nicotine with a volume of $1 \mathrm{~mL}, 2 \mathrm{~mL}$, and $4 \mathrm{~mL}$ for four weeks resulted in 
an increase in the bronchial mucosa thickness along with the increase in the volume of fluid used in the e-cigarette smoke exposure.

Based on the results of the Duncan Multiple Range Test, the mean alveolar septa thickness of the control group showed significant differences with the e-cigarette exposure treatment group with a liquid volume of $1 \mathrm{~mL}$ and $2 \mathrm{~mL}$, but not significantly different from the e-cigarette exposure treatment group with a liquid volume of $4 \mathrm{~mL}$. The mean alveolar septa thickness in the e-cigarette exposure treatment group with a liquid volume of $2 \mathrm{~mL}$ was not significantly different from the e-cigarette exposure treatment group with a fluid volume of $4 \mathrm{~mL}$, while the highest mean alveolar septa thickness was shown in the e-cigarette exposure treatment group with a liquid volume of $1 \mathrm{~mL}$. The mean alveolar septa thickness in the ecigarette exposure treatment group with a fluid volume of 1 $\mathrm{mL}, 2 \mathrm{~mL}$, and $4 \mathrm{~mL}$ was higher than the control group. This is thought to be due to nicotine present in the liquid used in e-cigarette exposure in mice. The difference in the effect of exposure to e-cigarettes with different volumes on alveolar thickness is thought to be because the increased ROS due to increased fluid volume directly affects alveolar lung damage in the form of alveolar septal destruction.

Exposure to e-cigarette smoke can cause thickening of the alveolar septa. Alveolar septa thickening can occur due to the accumulation of collagen in the alveolar septa. Nicotine exposure will lead to upregulation of Transforming Growth Factor- Beta 1 (TGF- $\beta 1$ ). TGF- $\beta 1$ will stimulate the Connective Tissue Growth Factor (CTGF), which is a marker for fibrogenesis, including collagen. Increased TGF- $\beta 1$ and CGTF will lead to increased extracellular matrix synthesis and fibroblast proliferation. The proliferation of fibroblasts will cause an increase in collagen deposition. The increase in collagen deposition causes the accumulation of collagen in the alveolar septa to increase, which results in an increase in the average thickness of the alveolar septa (Dasgupta et al., 2012). According to Wawryk-Gawda et al. (2020), exposure to electric cigarette smoke containing a dose of $12 \mathrm{mg} / \mathrm{mL}$ of nicotine by administering $0.6 \mathrm{~mL}$ to male Wistar rats for six weeks can cause eosinophil infiltration; erythrocytes; and mononuclear cells, thickening of the alveolar septa, and hyperemia. In this study, the thickening of the alveolar septa was thought to be caused by collagen deposition due to exposure to electric fumes.

In Table 1 , it appears that in the treatment group exposure to e-cigarette smoke with a fluid volume of $2 \mathrm{~mL}$ and $4 \mathrm{~mL}$ there was a decrease in the mean thickness of the alveolar septa, but did not show a significant difference. The treatment group exposed to e-cigarette smoke with a liquid volume of $4 \mathrm{~mL}$ showed the lowest mean alveolar septa thickness among the treatment groups and was not significantly different from the control group. The decrease in the mean thickness of the alveolar septa is thought to be due to the increase in fluid volume on exposure to ecigarette smoke which is also thought to damage the alveolar septa structure. Increasing the dose of fluid volume causes an increase in ROS which can inhibit $\alpha 1$-AT elastase, thus damaging the lung protein structure, one of which is the destruction of the alveolar septum (Hansel \& Barnes, 2004). The longer exposure time to e-cigarette smoke causes a higher degree of alveolar damage because an increase in ROS stimulates blood vessel expansion and increases inflammation in alveolar cells (Lulan, 2018).

E-cigarette smoke that gets into the alveoli can cause damage to the alveolar tissue. Exposure to cigarette smoke causes oxidative stress resulting in endothelial barrier dysfunction through inhibition of RhoA signals and focal adhesion kinase (FAK) (Lu et al., 2011). Cigarette smoke also causes a decrease in vascular endothelial growth factor (VEGF) and receptor 2 (VEGF R2), FAK, 1-antitrypsin (AAT), and unfolded protein response (UPR), which results in endothelial cell apoptosis (Lu et al., 2018). In addition, a decrease in VEGF and VEGF R2 will also cause apoptosis of alveolar septa (Kasahara et al., 2001) The existence of apoptosis in the alveolar septa and endothelial cells will cause a decrease in the mean thickness of the alveolar septa.

Histological structure of the alveolar septa in the treatment group that was given exposure to e-cigarette smoke with a fluid volume of $4 \mathrm{~mL}$ had much destruction and showed the widening of the alveolar wall. This is consistent with the research results by Reinikovaite et al. (2018), exposure to tobacco-flavoured e-cigarettes containing $48 \mathrm{mg} / \mathrm{mL}$ nicotine in male rats for five weeks significantly caused alveolar dilation as in conventional cigarettes. The widening of the alveoli and the destruction of the alveolar septa are thought to be due to the increase in fluid volume on exposure to e-cigarette smoke, which is also thought to increase the nicotine level inhaled ecigarette smoke. According to Lulan, (2018), the longer exposure time to e-cigarette smoke causes a higher lung damage score, such as the alveolar membrane is not intact and the relationship between the alveoli is increasingly tenuous.

E-cigarette smoke will cause an increase ROS levels in the body resulting in an imbalance between free radical compounds and antioxidants, resulting in oxidative stress. Oxidative stress will trigger an inflammatory reaction, increasing the production of ROS and activation of alveolar macrophages and neutrophil infiltration. Neutrophils will produce neutrophil elastase. Macrophage activation will cause the inactivation of the $\alpha$ protease, one inhibitor, namely $\alpha 1$-antitrypsin and the inhibitor of elastase (Santus et al., 2014). Inactivation of $\alpha_{\text {protease }}$ inhibitor will reduce 
the neutrophil elastase inhibitor, resulting in an imbalance between protease and antiprotease. This imbalance will cause an increase the activity of neutrophil elastase by breaking down elastin and collagen in the alveoli which can cause a decrease in the integrity and elasticity of the alveoli, causing alveolar destruction and alveolar dilation (Berawi \& Theodorus, 2017).

\section{Conclusions}

Exposure-cigarette smoke with different fluid volumes affects the bronchial mucosa's average thickness and the thickness of the alveolar septa. Exposure to the e-cigarette with a fluid volume of $1 \mathrm{~mL}$ increases the bronchiolar mucosa and alveolar septa thickness. Increasing the volume of fluid used results in an increase in the bronchial mucosa thickness, but decreases the thickness of the alveolar septa, resulting in destruction and dilation of the alveoli. It is necessary to conduct histopathological research of the bronchioles and alveoli of the lungs.

\section{Declaration statement}

The authors reported no potential conflict of interest.

\section{References}

Berawi, K. N., \& Theodorus, E. (2017). Alpha 1-antitrypsin Deficiency as a Risk Factor for Chronic Obstructive Pulmonary Disease. Majority, 6(2), 26-30.

Casebolt, R., Cook, S., Islas, A., Brown, A., Castle, K., \& Dutcher, D. (2019). Carbon Monoxide Concentration in Mainstream E-cigarette Emissions Measured with Diode Laser Spectroscopy. Tobacco Contro, 1-4. https://doi.org/10.1136/tobaccocontrol-2019-055078.

Dasgupta, C., Xiao, D., Xu, Z., Yang, S., \& Zhang, L. (2012). Developmental nicotine exposure results in programming of alveolar simplification and interstitial pulmonary fibrosis in adult male rats. Reprod Toxycol., $34(3)$,

370-377.

https://doi.org/10.1016/j.reprotox.2012.05.100

El Golli, N., Jrad-Lamine, A., Neffati, H., Rahali, D., Dallagi, Y., Dkhili, H., Ba, N., El May, M., \& El Fazaa, S. (2016). Impact of E-cigarette refill Liquid with or without nicotine on Liver Function in Adult Rats. Toxicology Mechanisms and Methods, 26(6), 419-426. https://doi.org/10.3109/15376516.2016.1160963

Garcia-Arcos, I., Geraghty, P., BaumLin, N., Campos, M., Dabo, A., Jundi, B., Cummins, N., Eden, E., Grosche, A., Salathe, M., \& Foronjy, R. (2016). Chronic electronic cigarette exposure in mice induces features of COPD in a nicotine-dependent manner. Thorax, 71(12), 111911299. https://doi.org/10.1136/thoraxjnl-2015-20803

Hansel, T. T., \& Barnes, P. J. (2004). An Atlas of Chronic Obstructive Pulmonary Disease. Parthenon Publishing Group.

Kasahara, Y., Tuder, R., Cool, C., Lynch, D., Flores, S., \& Voelkel, N. (2001). Endothelial Cell Death and Decreased
Expression of Vascular Endothelial Growth Factor and Vascular Endothelial Growth Factor Receptor 2 in Emphysema. American Journal of Respiratory and Critical Care Medicine., 163(31), 737-744. https://doi.org/10.1164/ajrccm.163.3.2002117

Kuschner, Ware, G., Reddy, S., Mehrotra, N., \& Paintal, H. (2011). Electronic Cigarettes and Thirdhand Tobacco Smoke: Two Emerging Health Care Challenges for the Primary Care Provider. International Journal of General Medicine, 4 , 115-120 https://doi.org/10.2147/IJGM.S16908.

Lerner, C., Sundar, I., Yao, H., Gerloff, J., Ossip, D., Mcintosh, S., Robinson, R., \& Rahman, I. (2015). Vapors Produced by Electronic Cigarettes and E-Juices with Flavorings Induce Toxicity, Oxidative Stress, And Inflammatory Response in Lung Epithelial Cells and in Mouse Lung. Plos One., 10(2), 1-26. https://doi.org/10.137/Journal.Pone.0116732.

Lu, Q., Gottlieb, E., \& Rounds, S. (2018). Effects of Cigarette Smoke on Pulmonary Endothelial Cells. American Journal of Physiology., 314(5), 743-756. https://doi.org/10.1152/Ajplung.00373.2017

Lu, Q., Sakhatskyy, P., Grinnell, K., Ortiz, J., Wang, Y., Sanchez-Esteban, J., Harrington, E., \& Rounds, S. (2011). Cigarette Smoke causes Lung Vascular Barrier Dysfunction Via Oxidative Stress-Mediated Inhibition of Rhoa and Focal Adhesion Kinase. American Journal of Physiology - Lung Cellular And Molecular Physiology., 301(6). https://doi.org/10.1152/Ajplung.00178.2011

Lulan, M. (2018). The Difference in Exposure Time to ECigarette Smoke Affects the Histopathological Picture of the Lungs of Mice (Mus Musculus). University Of Nusa Cendana.

Macnee, W., \& Rahman, I. (2001). Is Oxidative Stress Central to The Pathogenesis of Chronic Obstructive Pulmonary Disease? Trends in Molecular Medicine, 7(2), 55-62.

Meo, S., \& Al Asiri, S. (2014). Effects of Electronic Cigarette Smoking on Human Health. European Review For Medical And Pharmacological Sciences, 18(21), 33153319.

Mescher, A. (2016). Junqueras's Basic Histology Text and Atlas (14th ed.). Mc Graw-Hill Companies.

Nugroho, R. (2018). Knowing Mice as Laboratory Animals. Mulawarman University Press Samarinda.

Reinikovaite, V., Rodriguez, I., Karoor, V., Rau, A., Trinh, B., Frederic, W., \& Taraseviciene-Stewart, L. (2018). The Effects Of Electronic Cigarette Vapor On The Lung: Direct Comparison To Tobacco Smoke. European Respiratory Journal, 51(4), 1-8. https://doi.org/10.1183/13993003.01661-2017

Santus, P., Corsico, A., Solidoro, P., Braido, F., Di Marco, F., \& Scichilone, N. (2014). Oxidative Stress and Respiratory System: Pharmacological and Clinical Reappraisal of NAcetylcysteine. COPD: Journal of Chronic Obstructive 
Pulmonary $\quad$ Disease, 11(6), 705-717. https://doi.org/10.3109/15412555.2014.898040

Sartika, N., Winaya, I., Adi, A., \& Putra, I. (2018). Changes in Lung Histopathology of Male Mice After Exposure to ECigarette Smoke. Indonesia Medicus Veterinus, 7(4), 402-412. https://doi.org/10.19087/Imv.2018.7.4.402

Shu, J., Li, D., Ouyang, H., Huang, J., Long, Z., Liang, Z., Chen, Y., Chen, Y., Zheng, Q., Kuang, M., Tang, H., Wang, J., \& Lu, W. (2017). Comparison and Evaluation of Two Different Methods to Establish the Cigarette Smoke Exposure Mouse Model of COPD. Scientific Reports., 7(1), 1-11. https://doi.org/10.1038/S41598-017-15685-Y

Steel, R., \& Torie, J. (1993). Principles And Procedures Of Statistics (Biometric Approach). Gramedia Pustaka Utama.

Stevani, H. (2016). Pharmaceutical Print Material Module: Pharmacology Practicum.

http://bppsdmk.kemkes.go.id/Pusdiksdmk/Wp-

Content/Uploads/2017/08/Praktikum-Farmakologi-

Komprehensive.Pdf

Stratton, K., Kwan, L., \& Eaton, D. (2018). Public Health Consequences of E-Cigarettes. National Academies Press. https://doi.org/10.17226/24952

Suntoro, H. (1983). Methods of Staining, Histology and Histochemistry. Bhratara Karya Aksara.

Suryadinata, R. (2018). Effect of Free Radicals on The Inflammatory Process in Chronic Obstructive. Pulmonary Disease (Ppok). Amerta Nutr, 317-324. https://doi.org/10.20473/Amnt.V2.I4.2018.317-324

Tyner, J., Kim, E., Ide, K., Pelletier, M., Roswit, W., Morton, J., \& Battaile, J. (2006). Blocking Airway Mucous Cell Metaplasia by Inhibiting EGFR Antiapoptosis and IL-13 Transdifferentiation Signals. Journal of Clinical Investigation, 116(2), 309-321. https://doi.org//10.1172/JCI25167

Wawryk-Gawda, E., Wrzos, P., \& Zarobkiewicz, M. (2020). Lung Histomorphological Alterations In Rats Exposed To Cigarette Smoke And Electronic Cigarette Vapor. Experimental And Therapeutic Medicine., 19, 2826-2832. https://doi.org/10.3892/Etm.2020.8530 